\title{
Seismic Retrofitting of a Bridge Pier with Ultra High Performance Fibre Reinforced Concrete
}

\author{
Reggia Adriano ${ }^{1, *}$, Alessandro Morbi ${ }^{2}$, and Giovanni A. Plizzari ${ }^{1}$ \\ ${ }^{1}$ University of Brescia, DICATAM, 25123 Brescia, Italy \\ ${ }^{2}$ Global Product Innovation, Heidelberg Cement Group, 24126 Bergamo, Italy
}

\begin{abstract}
The increasing number of road infrastructures needing repair and retrofit is raising the problem of how to improve seismic behaviour for all those structures for which substitution is unlikely. This work deals with the application of a retrofitting technique for Reinforced Concrete (RC) elements based on the use of Ultra High Performance Fibre Reinforced Concrete (UHPFRC). A thin layer of UHPFRC, cast around an existing RC element, can both improve its structural performance and enhance its durability against environmental actions. This kind of rehabilitation intervention may represent, in many practical cases, a cost effective solution compared with the replacement of the entire structure. The aim of this paper is the definition of a reinforcement strategy and the presentation of a 1:4 scale laboratory test of a highway bridge pier reinforced with a $30 \mathrm{~mm}$ layer of UHPFRC.
\end{abstract}

\section{Introduction}

In the next few years, the number of Reinforcing Concrete $(\mathrm{RC})$ road transport infrastructures needing repair and retrofit is likely to increase in many Western countries. As an example, in a 2013 Report of the American Society of Civil Engineers, it has been estimated that about $11 \%$ of the 607,000 American bridges requires strengthening or seismic retrofitting due to structural deficiencies [1]. In Italy, some of the main highways were built between the $60 \mathrm{~s}$ and the $70 \mathrm{~s}$, before the introduction of the first seismic regulation in 1974 [2]. For instance, the A1 "Autostrada del sole" was completed in 1964, the A10 "Autostrada dei fiori" in 1971, and the A14 "Autostrada adriatica" in 1974.

In these 50 years, vehicles number and traffic loads have increased and seismic regulations have been introduced or renewed. For these reasons, it is the Authors' conviction that there is an extreme need to verify and to intervene on the safety of these infrastructures, especially on highway bridge piers. As a consequence, restoration of the load bearing capacity or seismic resistance improvement of existing RC bridges may become an important objective to be pursued for the development of constructions in many industrialized countries. But how the seismic behaviour of these structures can be improved?

This paper presents an application of Ultra High Performance Fibre Reinforced Concrete (UHPFRC) for seismic retrofitting of bridge piers which represents, in many cases, a faster and cost effective solution when compared to the substitution of the entire structure. In fact, costs related to the interruption of the road, the demolition of the bridge and the construction of the new one can be so high to make the replacement preferable just in cases of serious structural deficits. However, it should be noted that any further economical evaluation should be made only on the basis of the analysis of real cases and goes beyond the objectives of this work.

In fact, since Fibre Reinforced Concrete (FRC) came into market, thirty years ago, it was appreciated as a construction material for new structures [3] and rehabilitation of existing ones [4]. In particular, high values of compressive and tensile strength as well as a remarkably high toughness (given by fibres) helped to make UHPFRC a suitable material for rehabilitation of RC structures. Experiences around the world allowed FRC to enter into design codes of many Countries as well as in the fib Model Code 2010 [5].

The specific objective of this paper is the experimental demonstration of the possibility to enhance the seismic response of a highway bridge pier by means of the application of a thin layer of UHPFRC cast around the element, generally referred as jacketing. UHPFRC jacketing is designed to improve both the flexural and axial load bearing capacity at the design levels of the seismic action and the cracking control at lower levels. Furthermore, brittle failure mechanisms of the UHPFRC jacketing, such as buckling of the new layer, buckling of steel reinforcements, or concrete crushing will be investigated.

Compared to competitive solutions such as wrapping with FRP, jacketing with steel elements or with ordinary $\mathrm{RC}$ [6], jacketing with UHPFRC offers the possibility to renew the capacity of the element to resist to the environmental actions by means of the high durability of

* Corresponding author: adriano.reggia@unibs.it 
the new cement-based repair material. In fact, after a long exposure to the surrounding environment, concrete can be damaged by the combined action of different phenomena, such as carbonation, Alkali-Silika Reaction (ASR), sulphate attack, or other physical/chemical phenomena. Damage of concrete can accelerate the rate of corrosion of steel reinforcements and, then, the reduction of the flexural and axial load bearing capacity of the element.

Therefore, the substitution of damaged concrete on the external surface of the element with a new layer of UHPFRC can enhance both seismic response and durability of the element. As a result, nominal life $\left(\mathrm{V}_{\mathrm{N}}\right)$ of the structure can be extended from 50 to 100 years. Figure 1 shows a possible combined flexural and axial load interaction diagram of an highway bridge pier (described in paragraph 2.1) compared to one strengthened with a UHPFRC jacketing. Seismic actions shown in figure refer to a seismic acceleration with a probability of exceedance of $10 \%$ in 50 and 100 years. Should be noted that the extension of nominal life of 50 years is associated with an increase of seismic action of about $+33 \%$, while the enhancement of horizontal load bearing capacity (i.e. bending moment) can be more than $+45 \%$, for the considered value of vertical loads (i.e. axial force).

The highway bridge pier retrofitting technique is experimentally studied by means of a laboratory specimen scaled 1:4. The first objective is the experimental evaluation of the seismic response of the strengthened element by means of a cyclic loading test. A further objective is the development of a comprehensive retrofitting strategy that could be adopted by construction engineers and practitioners for real field applications.

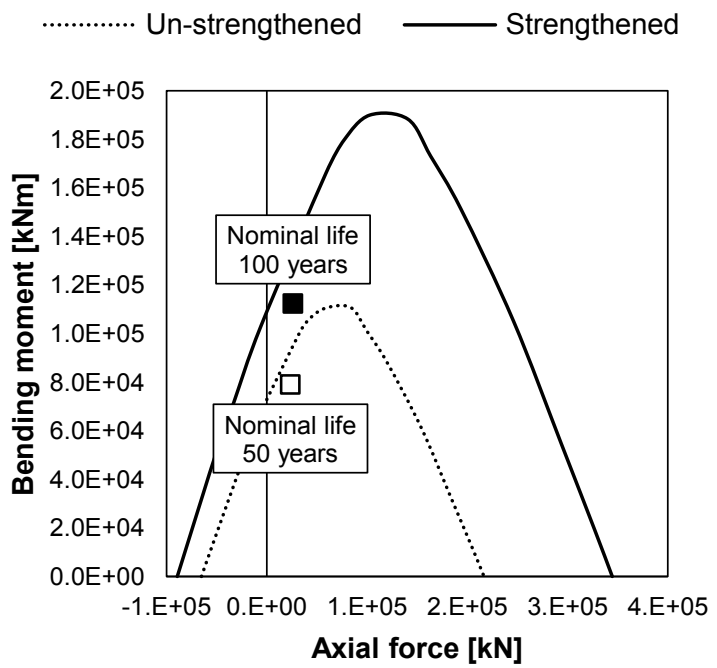

Fig. 1. Combined flexural and axial load interaction diagram of the real scale structure along the minor axis of inertia with seismic actions according to NTC 2008 [7].

\section{Experimental investigation}

\subsection{Design of the test}

The structural element under investigation is a typical highway bridge pier supporting three single-span box girders. The bridge pier is $23.32 \mathrm{~m}$ tall. It has a rectangular cross-section of $600 \times 250 \mathrm{~cm}$ with two internal cells of $210 \times 130 \mathrm{~cm}$. The thickness of the hollow cross-section is $60 \mathrm{~cm}$. The reinforcement in the critical section consists of $314 \varnothing 26$ longitudinal bars and $\varnothing 16$ transverse reinforcements spaced $100 \mathrm{~mm}$ with a concrete cover of $40 \mathrm{~mm}$. The cross-section area is equal to $9,385,960 \mathrm{~mm}^{2}$ and the total longitudinal reinforcement area is $164,588 \mathrm{~mm}^{2}$, corresponding to a reinforcement ratio of $1.75 \%$. Cross section of the real scale element is shown in Figure 2.

The laboratory specimen is obtained from the dimensions of the real scale structure with a geometric scale factor of 4 . The laboratory specimen has free length of $5.83 \mathrm{~m}$ and is globally $6.99 \mathrm{~m}$ tall. The crosssection is $150 \times 63 \mathrm{~cm}$ with two internal cells of $53 \times 32$ $\mathrm{cm}$. The wall thickness of the hollow cross section is 15 $\mathrm{cm}$. The reinforcement consists of $66 \varnothing 14$ longitudinal bars and $\varnothing 8$ transverse reinforcements spaced $100 \mathrm{~mm}$ with a concrete cover of $10 \mathrm{~mm}$. The cross-section area is equal to $596,250 \mathrm{~mm}^{2}$ and the total longitudinal reinforcement area is $10,160 \mathrm{~mm}^{2}$ corresponding to a reinforcement ratio of $1.70 \%$. Cross section of the reduced scale specimen is shown in Figure 2.

The design of the seismic retrofitting was performed in order to meet the requirements of an infrastructure of strategic importance, increasing the nominal life of the existing structure from 50 to 100 years. Seismic actions are calculated increasing the peak ground acceleration from $0.250 \cdot \mathrm{g}\left(\mathrm{V}_{\mathrm{N}}=50\right.$ years $)$ to $0.309 \cdot \mathrm{g}\left(\mathrm{V}_{\mathrm{N}}=100\right.$ years). A ground category $\mathrm{B}$, a topographic category $\mathrm{T} 2$ and a behaviour factor $\mathrm{q}=1.5$ are considered in the calculation, according to NTC 2008 [7]. As shown in Figure 1, the existing bridge pier does not guarantee structural safety under the new level of seismic load and, thus, a retrofitting intervention is required.

The seismic retrofitting of the real scale structure consist in the execution of a UHPFRC jacketing with a thickness equal to $120 \mathrm{~mm}$, scaled in the laboratory specimen to $30 \mathrm{~mm}$. An additional reinforcement was also provided to the new UHPFRC layer to restore the tensile capacity of the UHPFRC at the base section. The additional reinforcement is designed to yield when the UHPFRC reaches tensile strength, thus providing additional ductility to the section. The additional reinforcement is placed along the critical zone $(1 / 3$ of the height of the jacketing) and then anchored. In the laboratory specimen, the additional reinforcement consist of $26 \varnothing 12$ longitudinal bars placed on the front and back face, spaced $100 \mathrm{~mm}$, with a concrete cover of $10 \mathrm{~mm}$. The main design features are summarized in Table 1. 


\subsection{Specimens}

The laboratory specimen has been constructed in the "Laboratorio Pietro Pisa" of the University of Brescia in two stages.

1. Construction of the test specimen. The RC specimen was cast with a single batch of concrete of $7.3 \mathrm{~m}^{3}$. The RC element was cast horizontally in wooden formworks, cured for 28 days and, then, positioned vertically for testing. The specimen was characterized by the absence of cold joints or cracking (except shrinkage and thermal cracking) before the execution of the test.

2. Execution of the seismic retrofitting. Before placing the UHPFRC layer, the $\mathrm{RC}$ specimen was sandblasted to obtain a very rough surface $\left(\mathrm{R}_{\mathrm{t}}=3.0\right.$ $\mathrm{mm}$ ) measured with sand patch method [5]. The additional reinforcement was connected to the footing with chemical anchors in drilled holes. UHPFRC was made on site with a planetary mixer. The pouring of the UHPFRC layer was made in four stages using climbing lightweight formworks. Across cold joints, additional reinforcements were provided

Table 1. Main design features of the specimen: concrete area $\left(A_{C}\right)$, steel reinforcement area (As), UHPFRC thickness (tUHPFRC), steel reinforcement ratio $(\rho \mathrm{s})$, and additional steel reinforcement ratio ( $\rho$ s,added),

\begin{tabular}{|c|c|c|}
\hline & Real scale (1:1) & Reduced scale (1:4) \\
\hline $\mathrm{A}_{\mathrm{C}}$ & $9.386 \mathrm{~m}^{2}$ & $0.596 \mathrm{~m}^{2}$ \\
\hline $\mathrm{A}_{\mathrm{S}}$ & $164,588 \mathrm{~mm}^{2}$ & $10,160 \mathrm{~mm}^{2}$ \\
\hline$t_{\mathrm{UHPFRC}}$ & $120 \mathrm{~mm}$ & $30 \mathrm{~mm}$ \\
\hline$\rho_{\mathrm{S}}$ & $1.75 \%$ & $1.70 \%$ \\
\hline$\rho_{\mathrm{S}, \text { added }}$ & $0.65 \%$ & $0.65 \%$ \\
\hline
\end{tabular}

\subsection{Materials}

A Normal Strength Concrete (NSC) made with CEM II/A LL $32.5 \mathrm{R}$ cement, with a water/cement ratio 0.45 and containing Super Plasticizer (SP), has been used for the bridge pier. Maximum aggregate size was $10 \mathrm{~mm}$. A self-compacting UHPFRC made with CEM I $52.5 \mathrm{R}$ cement with a water/binder ratio 0.22 , with pozzolanic addition, Super Plasticizer (SP), Shrinkage Reducing Admixture (SRA) and steel fibres $\left(\mathrm{V}_{\mathrm{f}}=1 \%\right)$ has been used for the jacketing. Fibres were made of stainless steel, crimped, $19 \mathrm{~mm}$ long, with $0.13 \mathrm{~mm}$ diameter. The maximum aggregate size was $4 \mathrm{~mm}$ to fit the critical thickness of $30 \mathrm{~mm}$ of the jacketing. Mixture details of NSC and UHPFRC are given in Table 2. The main mechanical and physical properties were determined experimentally as follows: cubic compressive strength
(EN 12390-3:2009), indirect tensile strength (EN 123906:2010), elastic modulus (EN 12390-13:2013) and fracture toughness (EN 14651:2005). Hot rolled B450C steel has been used for the reinforcements of the bridge pier and added in the jacketing. Post-cracking behaviour of UHPFRC under flexure is shown in Figure 3.
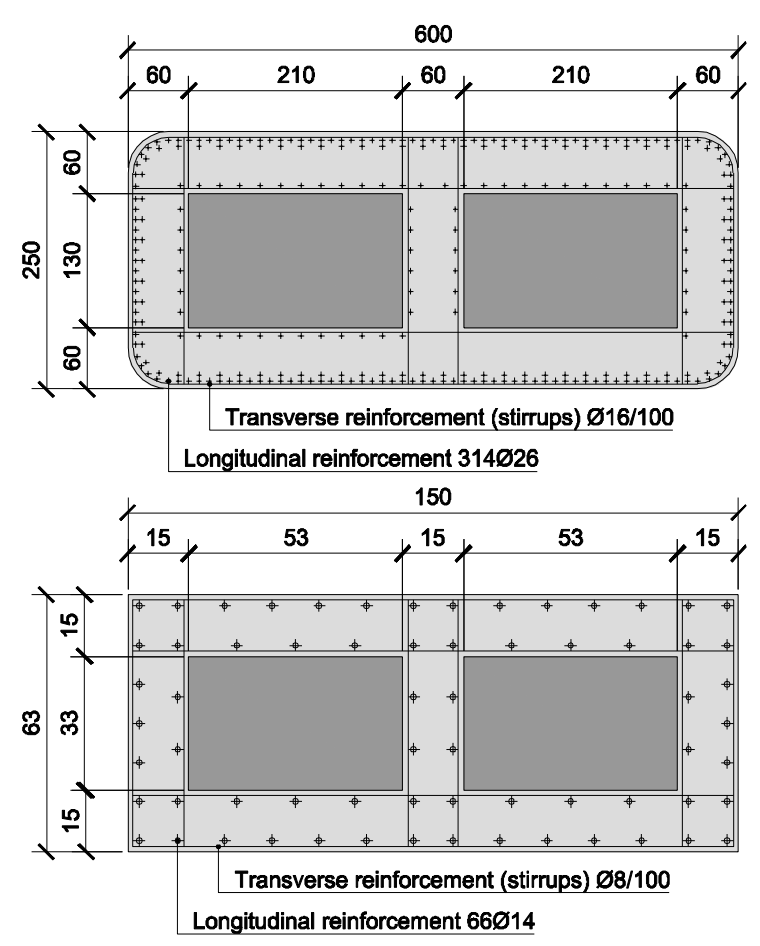

Fig. 2. Cross-section of the real scale structure (above) and reduced scale specimen (below). Measures in centimetres.

\subsection{Test setup}

The highway bridge pier laboratory specimen was tested at the "Laboratorio Pietro Pisa" of the University of Brescia. A static, uni-directional, cyclic loading test was performed along the minor axis of inertia as shown in Figure 4. A cyclic horizontal load $(\mathrm{H})$ was applied by means of an electro-mechanic actuator with a capacity of $1500 \mathrm{kN}$ connected to the strong wall. A constant vertical load $(\mathrm{V}=1000 \mathrm{kN})$ was applied through a steel spreader (2UPN400, S275 steel) loaded by two hydraulic jacks connected to the strong floor by means of two steel rods hinged at the base. The vertical load $(\mathrm{V})$ has been designed by setting $\mathrm{V} / \mathrm{f}_{\mathrm{c}} \mathrm{A}_{\mathrm{c}}=0.05$ with $\mathrm{f}_{\mathrm{c}}=35 \mathrm{MPa}\left(\mathrm{f}_{\mathrm{c}}=\right.$ $\left.0.83 \cdot f_{c, \text { cube }}\right)$ as nominal compressive strength. Rotation of the footing was prevented using ten post-tensioned steel rods connected to the strong floor. Two post tensioned rods (in tension) and two RC beams (in compression) were used to prevent sliding of the foundation from the strong wall. 
Table 2. NSC and UHPFRC composition (volume ratio on total binder).

\begin{tabular}{|c|c|c|}
\hline & NSC & UHPFRC \\
\hline $\begin{array}{c}\text { Water/binde } \\
\text { r ratio }\end{array}$ & 0.45 & 0.22 \\
\hline Aggregates & 6.17 & 1.85 \\
\hline $\begin{array}{c}\text { Pozzolanic } \\
\text { addition }\end{array}$ & - & 0.034 \\
\hline $\begin{array}{c}\text { SP } \\
\text { admixtures }\end{array}$ & 0.035 & 0.030 \\
\hline $\begin{array}{c}\text { SRA } \\
\text { admixtures }\end{array}$ & - & 0.031 \\
\hline Steel fibres & - & 0.04 \\
\hline
\end{tabular}

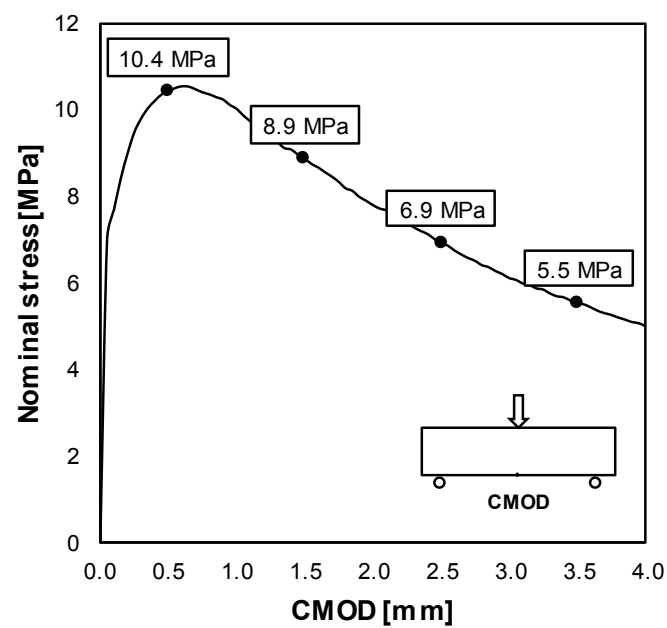

Fig. 3. Average response curve of UHPFRC (3 specimens) under three point bending according to EN 14651:2005.

\subsection{Test program}

The laboratory specimen was tested under cyclic loading in the north-south direction with the drift-controlled protocol shown in Table 3. The drift $(\theta)$ was defined as the ratio between the lateral displacement (d) at the point of application of the horizontal load $(\mathrm{H})$ and the distance between the same point at the base of the element. Initially, the first test was carried out on the unstrengthened laboratory specimen up to the first cracking of the $\mathrm{RC}$ element. The maximum drift reached in the first test was equal to $0.25 \%$. Afterwards, a second test was performed after the execution of the retrofitting up to the failure of the strengthened element. The maximum drift reached in the second test was equal to $3.4 \%$. The first test was carried out at the Serviceability Limit State
(SLS) to simulate the damage accumulated during service life of the bridge pier due to wind pressure, inertial forces due to vehicular movement and lower than design-level earthquakes. The second test was performed at the Ultimate Limit State (ULS) to evaluate the seismic response of the strengthened element.

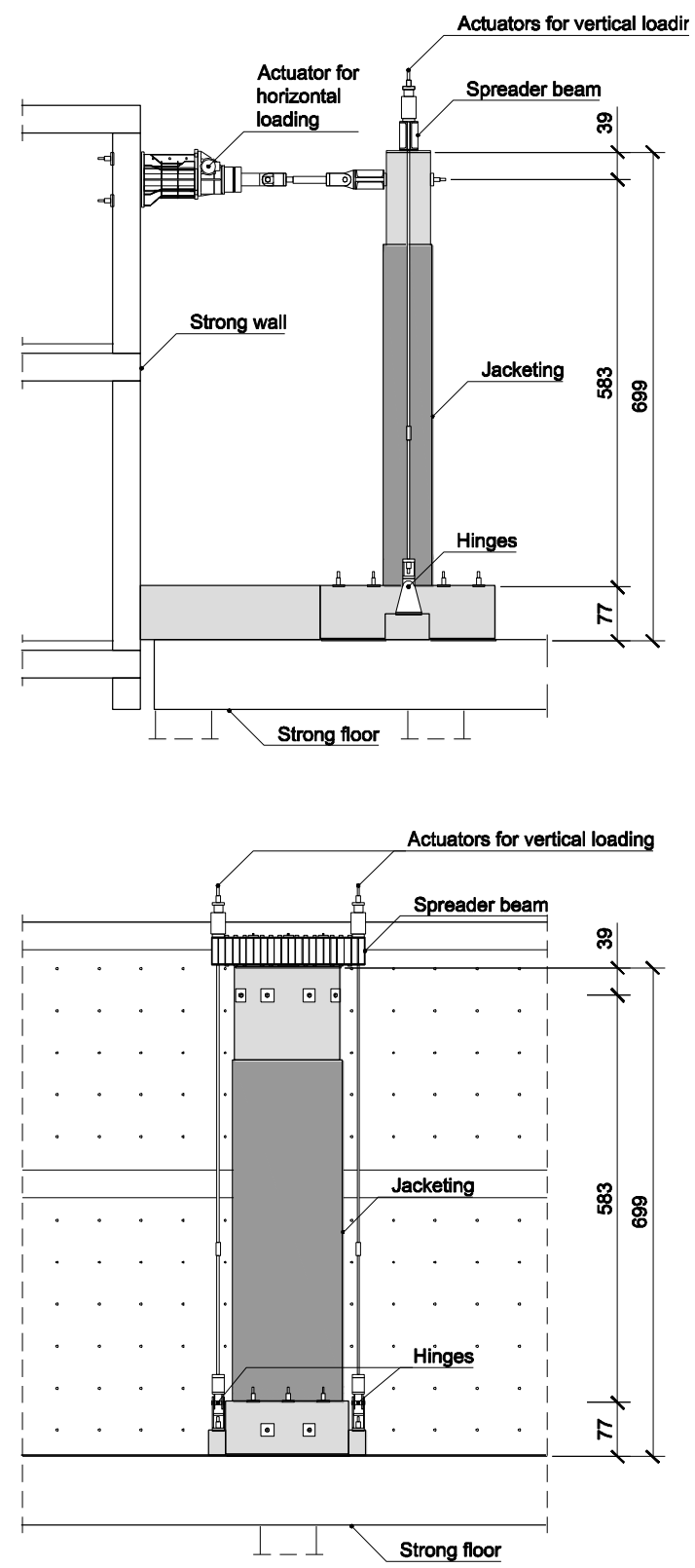

Fig. 4. Test setup: lateral view (above) and front view (below) 
Table 3. Test program.

\begin{tabular}{|c|c|c|c|}
\hline Test 1 & $\begin{array}{c}\mathbf{d} \\
{[\mathrm{mm}]}\end{array}$ & $\begin{array}{c}\boldsymbol{\theta} \\
{[\%]}\end{array}$ & Cycles \\
\hline Step 1 & 2.5 & 0.05 & 3 \\
\hline Step 2 & 5 & 0.1 & 3 \\
\hline Step 3 & 12.5 & 0.25 & 3 \\
\hline Test 2 & $\begin{array}{c}\mathbf{d} \\
{[\mathrm{mm}]}\end{array}$ & $\begin{array}{c}\theta \\
{[\%]}\end{array}$ & Cycles \\
\hline Step 1 & 2.5 & 0.05 & 3 \\
\hline Step 2 & 5 & 0.1 & 3 \\
\hline Step 3 & 10 & 0.2 & 3 \\
\hline Step 4 & 15 & 0.25 & 3 \\
\hline Step 5 & 20 & 0.35 & 3 \\
\hline Step 6 & 25 & 0.4 & 3 \\
\hline Step 7 & 50 & 1.0 & 3 \\
\hline Step 8 & 75 & 1.3 & 3 \\
\hline Step 9 & 100 & 1.7 & 3 \\
\hline Step 10 & 125 & 2.1 & 3 \\
\hline Step 11 & 150 & 2.6 & 3 \\
\hline Step 12 & 200 & 3.4 & 3 \\
\hline
\end{tabular}

\section{Experimental results and discussion}

\subsection{Material's properties}

Compressive strength of NSC was measured after 28 days, for strength class determination, after 210 days, at the beginning of the first test (un-strengthened specimen), and after 270 days, at the beginning of the second test (strengthened specimen). Compressive strength $\left(\mathrm{f}_{\mathrm{c}, \text { cube }}\right)$ was found $42.5 \mathrm{MPa}, 48.4 \mathrm{MPa}$, and $49.5 \mathrm{MPa}$ respectively. According to Eurocode 2 [8] strength class of NSC was C25/30. Indirect tensile strength was measured after 210 days and 270 days to be equal to $3.4 \mathrm{MPa}$ and $3.5 \mathrm{MPa}$, respectively. At the same concrete ages, modulus of elasticity was found equal to 34,510 MPa and 36,035 MPa.

Compressive strength, indirect tensile strength and elastic modulus of UHPFRC were experimentally determined after 28 days at the beginning of the second test (strengthened specimen). Compressive strength ( $f_{c, \text { cube }}$ ) was found 136.3 MPa. According to Eurocode 2
[8] strength class of UHPFRC was the highest class: C90/105. Indirect tensile strength was $14.2 \mathrm{MPa}$ and elastic modulus was $44,879 \mathrm{MPa}$. Post-cracking behaviour was tested by means of three-point bending testing on notched beams. Flexural residual strengths significant for $\operatorname{SLS}\left(f_{R 1}\right)$ and for $\operatorname{ULS}\left(f_{R 3}\right)$ were 10.4 $\mathrm{MPa}$ and $6.9 \mathrm{MPa}$, respectively. According to Model Code 2010 (MC2010) [5], post-cracking strength class was 5 a.

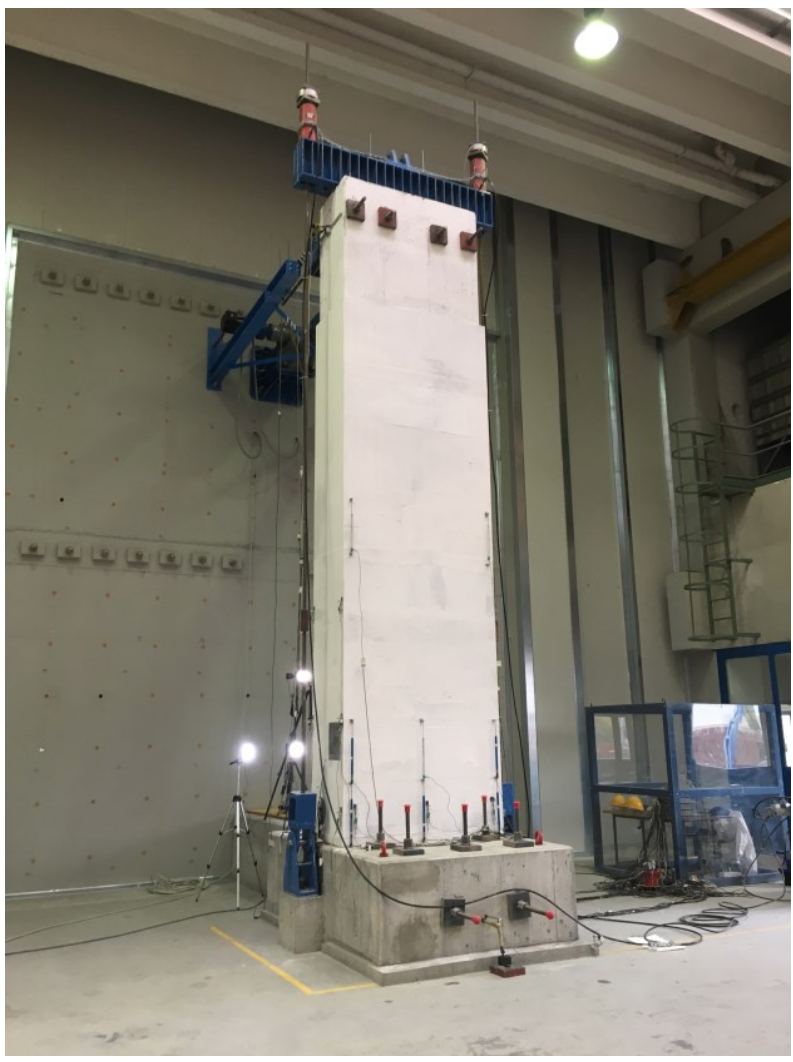

Fig. 5. View of the strengthened specimen.

\subsection{Seismic response}

Figure 6 shows the seismic response of the strengthened element (i.e. Test 2) measured as the horizontal displacement (d) versus the horizontal load (H). Positive displacements correspond to a movement toward the strong wall (northward direction). The strengthened specimen reached a maximum load of $451 \mathrm{kN}$ during cycle with $\theta=3.4 \%(\mathrm{~d}=200 \mathrm{~mm})$ in the northward direction. While in the northward direction the lateral load continued growing up to the end of the test, in the southward direction resistance reached a maximum value of $407 \mathrm{kN}$ during cycle with $\theta=1.7 \%(\mathrm{~d}=100 \mathrm{~mm})$ followed by a reduction $(-12 \%)$ to $360 \mathrm{kN}(80.940)$ with $\theta=3.4 \%(\mathrm{~d}=200 \mathrm{~mm})$. After reaching the maximum drift $(\theta=3.4 \% ; d=200 \mathrm{~mm})$, buckling of the jacketing was observed at the base of the south face (front). After the local delamination of the UHPFRC jacketing, a reduction of the stiffness of the element was observed and the test was interrupted to avoid any dangerous collapse. 


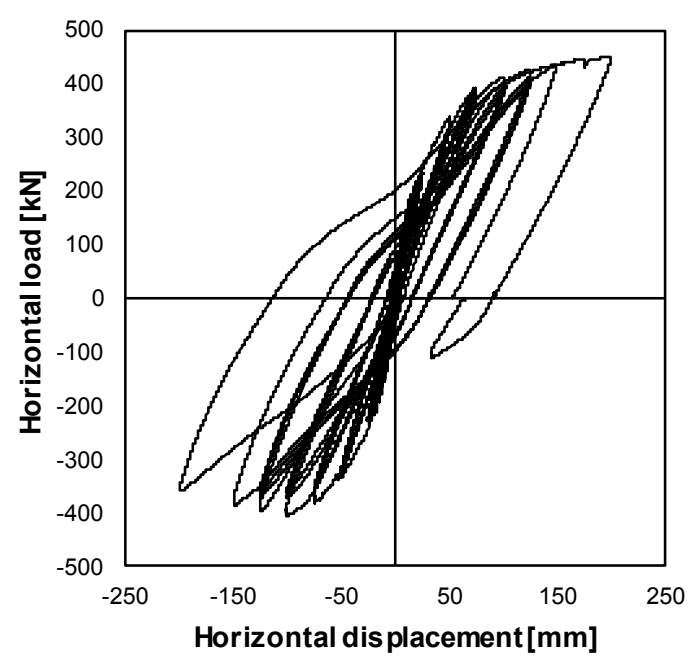

Fig. 6. Structural response of the strengthened specimen.

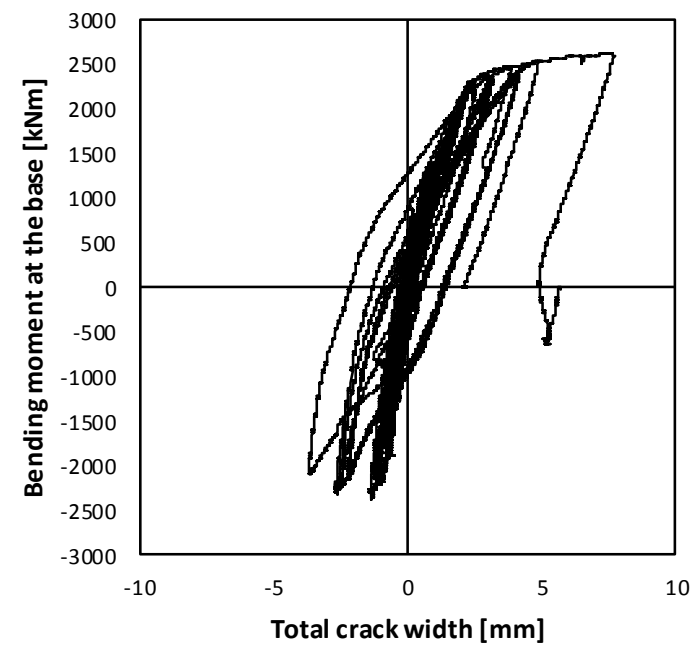

Fig. 7. Total crack width development at the base of the strengthened specimen (measurement length of $1000 \mathrm{~mm}$ ).

\subsection{Damage assessment}

Figure 7 shows the total crack width at the base of the element measured on a length of $1000 \mathrm{~mm}$ versus the bending moment. Positive values correspond to the increase of the width of the cracks. Figure 8 shows the crack pattern on the front face at the end of each test. The UHPFRC showed an excellent ability to control cracking: a diffused pattern of cracks developed up to $\theta$ $=1.0 \%(\mathrm{~d}=50 \mathrm{~mm})$. At this level of drift, the average maximum crack width was $0.190 \mathrm{~mm}$ and the average crack spacing was $98 \mathrm{~mm}$ (see Figure 9 and Figure 10). First cracks near the base of the element were observed at $\theta=0.1 \%(\mathrm{~d}=5 \mathrm{~mm})$, with an average crack width equal to $0.087 \mathrm{~mm}$. First splitting cracks were observed at $\theta=0.3 \%(\mathrm{~d}=15 \mathrm{~mm})$; at the same drift level, the opening of a cold joint was observed (anyhow limited by local reinforcement). At $\theta=1.7 \%(\mathrm{~d}=100 \mathrm{~mm})$ a crack formed on the base section, where UHPFRC jacketing was anchored to the RC basement. At this level of drift, the average maximum crack width was $0.276 \mathrm{~mm}$ and the average crack spacing was $85 \mathrm{~mm}$. For drift values higher than $\theta=1.7 \%$, no additional cracks formed but those already formed developed due to the yielding of reinforcement bars contained in the jacketing with a visible accumulation of the damage. At the end of the test the average maximum crack width was $0.683 \mathrm{~mm}$ and the crack spacing equal to $85 \mathrm{~mm}$. No spalling, exposure or fracture of reinforcements were observed at the end of the test.
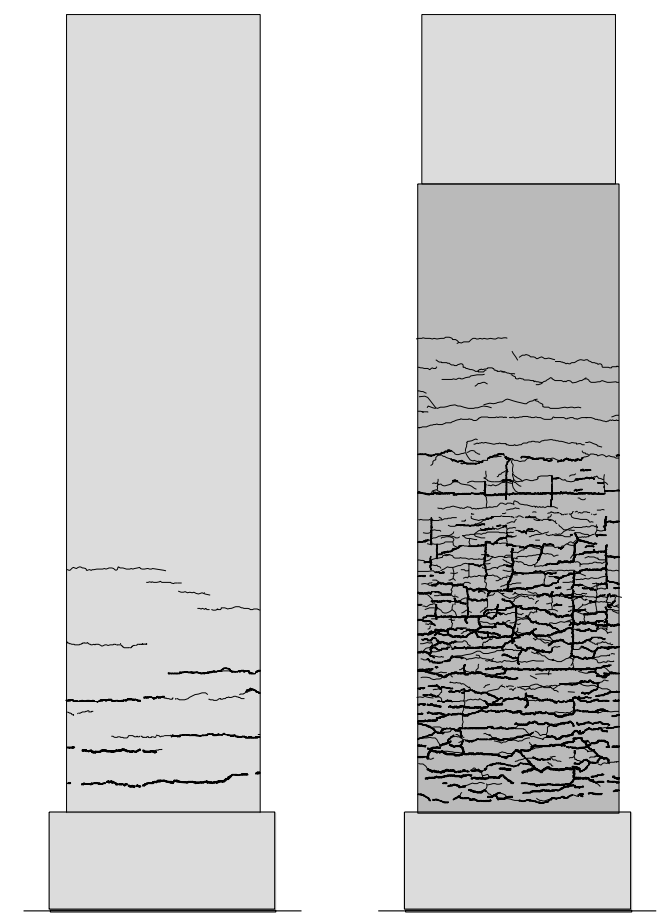

Fig. 8. Crack pattern of the front face of the un-strengthened specimen (left) after Step 3 (Drift 0.25\%) and strengthened specimen (right) after Step 9 (Drift 1.7\%).

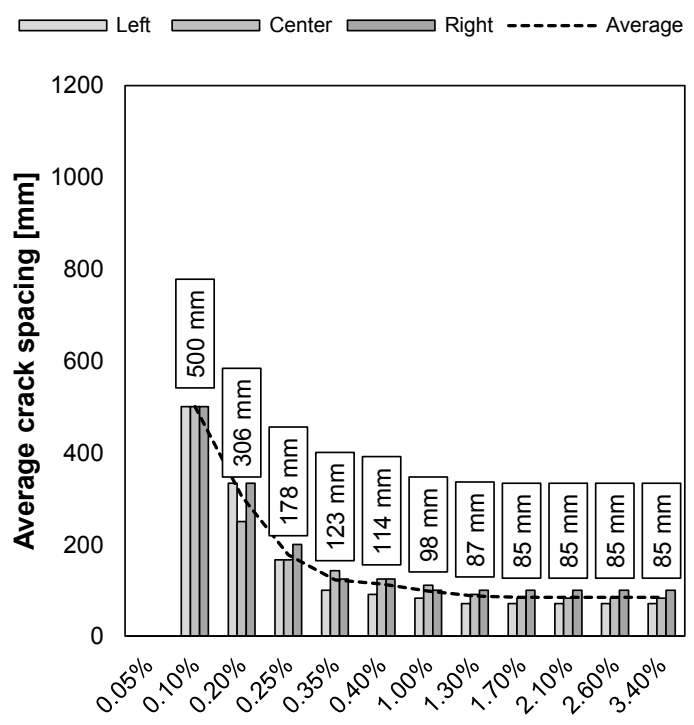

Fig. 9. Crack spacing development at the base of the strengthened specimen over the test cycles (measurement length of $1000 \mathrm{~mm}$ ). 


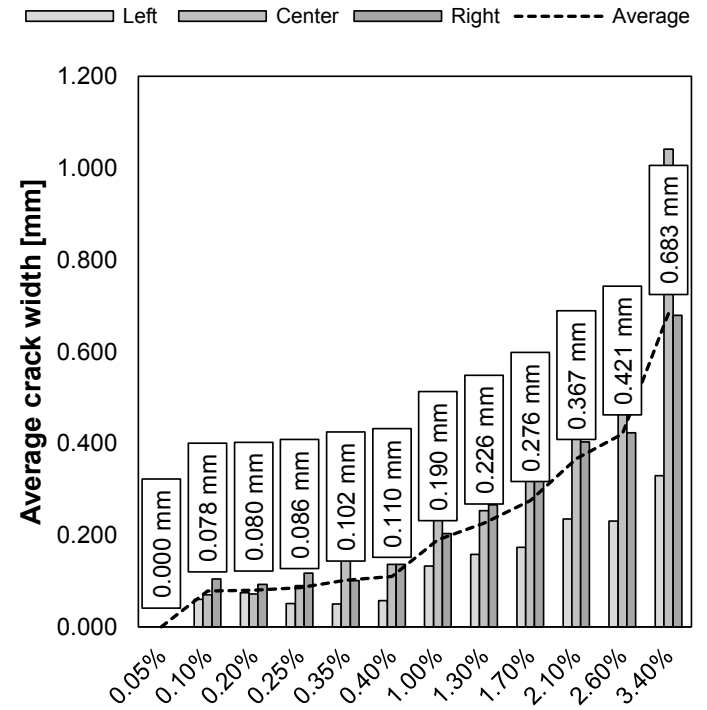

Fig. 10. Crack width development at the base of the strengthened specimen over the test cycles (measurement length of $1000 \mathrm{~mm}$ ).

\subsection{Discussion}

Since the structural response of the un-strengthened specimen was not fully determined experimentally, the full structural response was predicted by means of a nonlinear analysis based on the sectional theory. The loaddisplacement curve, shown in Figure 11 with a dashed line, has been estimated by the integration of the curvature due to the bending moment in the element. The non-linear behaviour of materials was considered in the determination of the moment-curvature relationship according to Eurocode 2 [8]. Seismic response of the strengthened specimen, compared with the unstrengthened specimen in Figure 11, is enhanced both in the maximum load and in the maximum displacement reached at the end of the test. Table 4 summarizes this enhancement in terms of maximum horizontal force $(\mathrm{H})$, maximum displacement (d), and maximum drift $(\theta)$. The ultimate load increased up to $+74 \%$ with respect to the theoretical prediction and the ultimate displacement increased up to $+57 \%$. The load determining first cracking and the first yielding of steel reinforcements increased up to $+42 \%$ and $+90 \%$ respectively, with respect to the theoretical prediction.

\section{Conclusions}

Safety of existing road infrastructures with more than 50 years will become a topic of great importance in the coming years, mainly for three reasons: reduction of the combined flexural and axial load bearing capacity of the elements due to degradation of concrete and corrosion of reinforcements; increase of the number of vehicles and vehicle loads; introduction or renewal of seismic regulations, according to which structures may not have been designed.

Therefore, valuable and reliable retrofitting strategies are required to provide or restore structural safety with particular regard to the effects of an earthquake. Seismic retrofitting must represent an efficient and cost effective solution where the substitution of the entire structure is not possible or extremely expensive. New cement-based materials, as UHPFRC, offer a promising solution to structural safety and durability enhancement of existing $\mathrm{RC}$ road transport infrastructures.

Table 4. Key performance indexes: maximum horizontal force $(\mathrm{H})$, maximum horizontal displacement $(\mathrm{d})$ and maximum $\operatorname{drift}(\theta)$.

\begin{tabular}{|c|c|c|c|}
\hline $\begin{array}{c}\text { First } \\
\text { cracking }\end{array}$ & $\begin{array}{c}\mathbf{H} \\
{[\mathbf{k N}]}\end{array}$ & $\begin{array}{c}\mathbf{d} \\
{[\mathbf{m m}]}\end{array}$ & $\begin{array}{c}\mathbf{\theta} \\
{[\mathbf{\%}]}\end{array}$ \\
\hline $\begin{array}{c}\text { Un- } \\
\text { strengthened }\end{array}$ & 70 & 5.8 & 0.1 \\
\hline Strengthened & $\begin{array}{c}100 \\
(+42 \%)\end{array}$ & $\begin{array}{c}5 \\
(-14 \%)\end{array}$ & $\begin{array}{c}0.1 \\
(-14 \%)\end{array}$ \\
\hline First yielding & $\begin{array}{c}\mathbf{H} \\
{[\mathbf{k N}]}\end{array}$ & $\begin{array}{c}\mathbf{d} \\
{[\mathbf{m m}]}\end{array}$ & $\begin{array}{c}\boldsymbol{\theta} \\
{[\mathbf{\%}]}\end{array}$ \\
\hline $\begin{array}{c}\text { Un- } \\
\text { strengthened }\end{array}$ & $208^{*}$ & $49 *$ & $0.8 *$ \\
\hline $\begin{array}{c}\text { Strengthened } \\
\text { Failure }\end{array}$ & $\begin{array}{c}395 \\
(+90 \%)\end{array}$ & $\begin{array}{c}75 \\
(+53 \%)\end{array}$ & $\begin{array}{c}1.3 \\
(+53 \%)\end{array}$ \\
\hline $\begin{array}{c}\text { Un- } \\
\text { strengthened }\end{array}$ & $259^{*}$ & $\begin{array}{c}\mathbf{d} \\
{[\mathbf{m m}]}\end{array}$ & $\begin{array}{c}\mathbf{\theta} \\
{[\mathbf{\%}]}\end{array}$ \\
\hline Strengthened & $\begin{array}{c}451 \\
(+74 \%)\end{array}$ & $\begin{array}{c}200 \\
(+57 \%)\end{array}$ & $\begin{array}{c}2.2 * \\
(+57 \%)\end{array}$ \\
\hline
\end{tabular}

*Calculated values with $\mathrm{f}_{\mathrm{y}}=450 \mathrm{MPa}$.

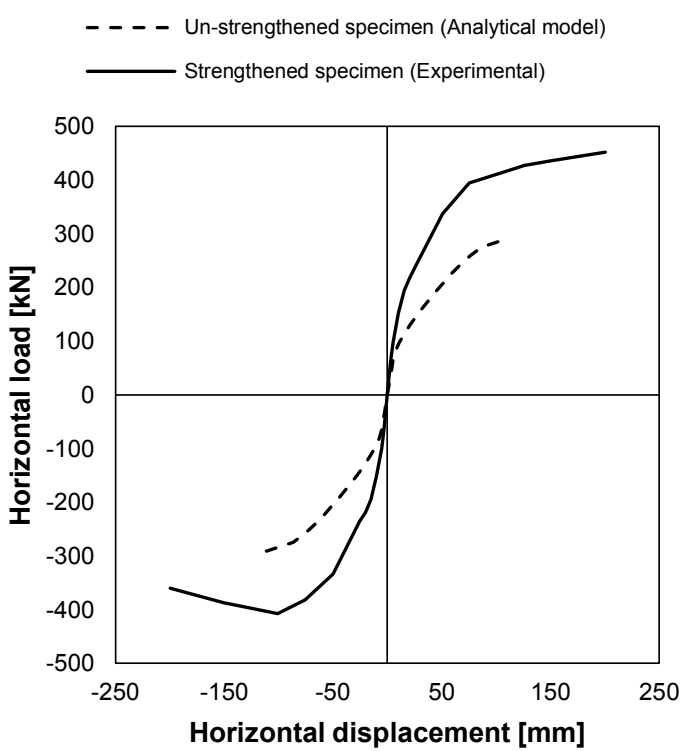

Fig. 11. Comparison between the structural response of the strengthened specimen (envelope of the response curve) and the un-strengthened specimen (analytical model prediction).

Based on the experimental study herein presented, the following conclusions can be drawn: 
1. UHPFRC jacketing can be successfully carried out around an existing $\mathrm{RC}$ bridge pier even with a small thickness (t $\mathrm{t}_{\text {UHPFRC }}=30 \mathrm{~mm}$ ). This reinforcement strategy can be adopted for applications requiring small thicknesses, as it has been experimentally tested, or large thicknesses, as it can be designed for the real scale retrofitting.

2. UHPFRC jacketing improved the seismic response at ULS enhancing the ultimate load $(+74 \%)$ with respect to the un-strengthened element. UHPFRC jacketing may be considered in further studies as a promising technique for seismic retrofitting of bridge piers.

3. UHPFRC jacketing improved the structural behaviour at SLS determining a diffused pattern of micro-cracks with small values of average crack width and, thus, a lower ease of penetration of aggressive substances inside the structure for lower than design-level earthquake intensity.

The Authors wish to express their gratitude and sincere appreciation to Italcementi and Global Product Innovation HEIDELBERG Cement Group for financing this research work and other on-going research projects related to innovative applications of High Performance Concrete. A special thank goes to Mr Mattia Ferrari for his support in carrying out the experimental program. Mr Augusto Botturi, Mr Domenico Caravaggi, Mr Andrea Del Barba, and Mr Domenico Fiorillo are warmly thanked for their technical support during laboratory activities.

\section{References}

1. ASCE, 2013 Report card for America's infrastructure, (2013)

2. Repubblica Italiana, L. 2 febbraio 1974, n. 64, in materia di "Provvedimenti per le costruzioni con particolari prescrizioni per le zone sismiche" (1974)

3. M. Di Prisco, G. Plizzari, L. Vandewalle, Mat. and Str., 42 (9), 1261-1281 (2009)

4. A. Reggia, F. Macobatti, F. Minelli, G. A. Plizzari, S. Sgobba, Proceedings of the 4th International Conference on Concrete Repair, Rehabilitation and Retrofitting (ICCRRR-4), (2015)

5. Fédération Internationale du Béton, fib Model Code for Concrete Structures 2010, 1-2, (2012)

6. M. N. Priestley, F. Seible, G. M. Calvi, Seismic design and retrofit of bridges, John Wiley \& Sons (1996)

7. Repubblica Italiana, D.M. 14 gennaio 2008, in materia di "Approvazione delle nuove norme tecniche per le costruzioni” (2008)

8. CEN, EN 1992-1-1:2004, (2004) 